\title{
Safety of Pseudomonas chlororaphis as a gene source for genetically modified crops
}

\author{
Jennifer A. Anderson $•$ Jamie Staley $\cdot$ Mary Challender $\cdot$ Jamie Heuton
}

Received: 16 August 2017/ Accepted: 30 January 2018/Published online: 9 February 2018

(C) The Author(s) 2018. This article is an open access publication

\begin{abstract}
Genetically modified crops undergo extensive evaluation to characterize their food, feed and environmental safety prior to commercial introduction, using a well-established, science-based assessment framework. One component of the safety assessment includes an evaluation of each introduced trait, including its source organism, for potential adverse pathogenic, toxic and allergenic effects. Several Pseudomonas species have a history of safe use in agriculture and certain species represent a source of genes with insecticidal properties. The ipd072Aa gene from $P$. chlororaphis encodes the IPD072Aa protein, which confers protection against certain coleopteran pests when expressed in maize plants. $P$. chlororaphis is ubiquitous in the environment, lacks known toxic or allergenic properties, and has a history of safe use in agriculture and in food and feed crops. This information supports, in part, the safety assessment of potential traits, such as IPD072Aa, that are derived from this source organism.
\end{abstract}

Keywords Genetically modified crops · Pseudomonas chlororaphis $\cdot$ Safety assessment . Insect protection - Agricultural biotechnology

J. A. Anderson $(\bowtie) \cdot J$. Staley $\cdot$ M. Challender .

J. Heuton

DuPont Pioneer, 8325 NW 62nd Avenue, Johnston,

IA 50131, USA

e-mail: jennifer.anderson@ pioneer.com

\section{Introduction}

Genetically modified (GM) crops were first commercialized in the mid-1990s and currently are planted on over $90 \%$ of corn, cotton and soybean acres in the United States (USDA-NASS 2017). GM crop adoption continues to increase globally, due to their economic and sustainability benefits (Anderson et al. 2016; ISAAA 2016). Most commercial GM crops containing insect protection traits currently rely on genes derived from Bacillus thuringiensis (Bt) to provide selective protection against economically important pests. The safety of $B t$ as a source of insecticidal genes for GM crops is well established (Box 1). Bt was initially developed as a microbial pesticide spray and has a history of safe use in agriculture when applied, as intended, on food and feed crops (US-EPA 1998). Bt is ubiquitous in the environment (Schnepf et al. 1998), non-toxic to mammals and does not have pathogenic or allergenic properties (US-EPA 1998).

Pseudomonads are rod-shaped, aerobic, gram-negative bacteria. Certain Pseudomonas species have previously been reported to have entomopathogenic properties and represent a promising source of insecticidal genes for use in GM crops (Kupferschmied et al. 2013). A gene, ipd072Aa, from Pseudomonas chlororaphis, which encodes the IPD072Aa protein, has recently been reported to confer protection against certain coleopteran pests when expressed in maize plants (Schellenberger et al. 2016). 
The safety assessment framework for GM crops is well established and has been adopted globally to evaluate a variety of trait types, including those for insect protection (Codex Alimentarius Commission 2009; EFSA 2006; FAO/WHO 1991). The assessment includes, in part, an evaluation of each introduced trait, including its source organism, for potential adverse pathogenic, toxic and allergenic effects (Delaney et al. 2008). This paper provides an assessment of the safety of $P$. chlororaphis as a gene source for GM crops. Like Bt, certain species of Pseudomonas including $P$. chlororaphis are ubiquitous in the environment, have a history of safe use in agriculture as seed treatments, foliar-applied biopesticides and as a gene source for GM crops, and lack known pathogenic, toxic or allergenic properties. This information supports, in part, the safety assessment of potential traits, such as IPD072Aa, derived from this source organism.

\section{Ubiquity in the environment}

The genus Pseudomonas has been well studied and is estimated to contain over 100 species and 10 subspecies (Gomila et al. 2015; Peix et al. 2009). Sequence analysis of conserved housekeeping genes has provided information on the phylogenetic relatedness of Pseudomonas species within the genus (Anzai et al. 2000; Garrity et al. 2005; Gomila et al. 2015; Moore et al. 2006). Pseudomonas species have been classified into 7 groups: $P$. syringae, $P$. chlororaphis, $P$. fluorescens, $P$. putida, $P$. stutzeri, $P$. aeruginosa and P. pertucinogena (Anzai et al. 2000; Fig. 1). $P$. chlororaphis contains four subspecies: P. chlororaphis subsp. aurantiaca, $P$. chlororaphis subsp. aureofaciens, P. chlororaphis subsp. chlororaphis and P. chlororaphis subsp. piscium (Burr et al. 2010).

Most Pseudomonas species, including P. chlororaphis, are ubiquitous in the environment, have
Fig. 1 Phylogenetic tree of the authentic Pseudomonas derived from the similarities of the $16 \mathrm{~S}$ rDNA sequence. Bootstrap percentages of $80 \%$ or more are indicated at the branch points. Escherichia coli (V00348) is used as the root organism. Symbols: *previously $P$. coronafaciens; ${ }^{\dagger}$ previously $P$. aureofaciens. Reproduced with permission from Anzai et al. 2000, (C) International Union of Microbiological Sciences

widespread distribution in soil and water (Peix et al. 2009) and perform a range of economic services and ecological functions. Some Pseudomonas species inhabit the rhizosphere, are associated with plant roots and provide benefits to the plant by competing with soil-borne plant pathogens and protecting against fungal pests (Anderson and Kim 2018; Kupferschmied et al. 2013; Mauchline and Malone 2017). P. chlororaphis, specifically, has been reported to promote plant growth, stimulate microbial communities and protect plants by producing compounds (e.g., phenazine-type antibiotics, hydrogen cyanide, chitinases and proteases) that inhibit fungal growth (EFSA 2015b), insects and nematodes (Anderson and Kim 2018). Other Pseudomonas species protect plants by preventing colonization by deleterious microorganisms (Mendes et al. 2011).

Certain Pseudomonas species have been utilized in a variety of applications, including the biological control of phytopathogens (Walsh et al. 2001), promotion of plant growth (Mercado-Blanco and Bakker 2007), phosphate solubilization (Rodríguez and Fraga 1999) and bioremediation of organic compounds (Moore et al. 2006; Peix et al. 2009). Many Pseudomonas species have a history of safe use in agriculture and other sectors (EFSA 2015b; Montie 1998). For example, certain Pseudomonas species are entomopathogenic and are being utilized as biopesticides to provide plant protection against insect pests. Insecticidal toxins in the genome of $P$. entomophilia have been identified (Luiu et al. 2013), and P. fluorescens has been shown to exert insecticidal activity against aphids, termites and other agricultural pests

Box 1 Weight of evidence supporting the safety of Bacillus thuringiensis (Bt) as a source of insecticidal genes

Presence in the environment-ubiquitous, both in soil and on plants (Schnepf et al. 1998)

History of safe use in the field of agriculture-Bt products were initially developed as microbial pesticide sprays and have been approved for use on multiple food and feed crops (US-EPA 1998)

Phylogenetic relatedness to known human pathogens-Bt is not closely related to known human pathogens

Known mammalian toxic, pathogenic or allergenic potential- Bt is not toxic to mammals and has no known pathogenic or allergenic potential (US-EPA 1998) 


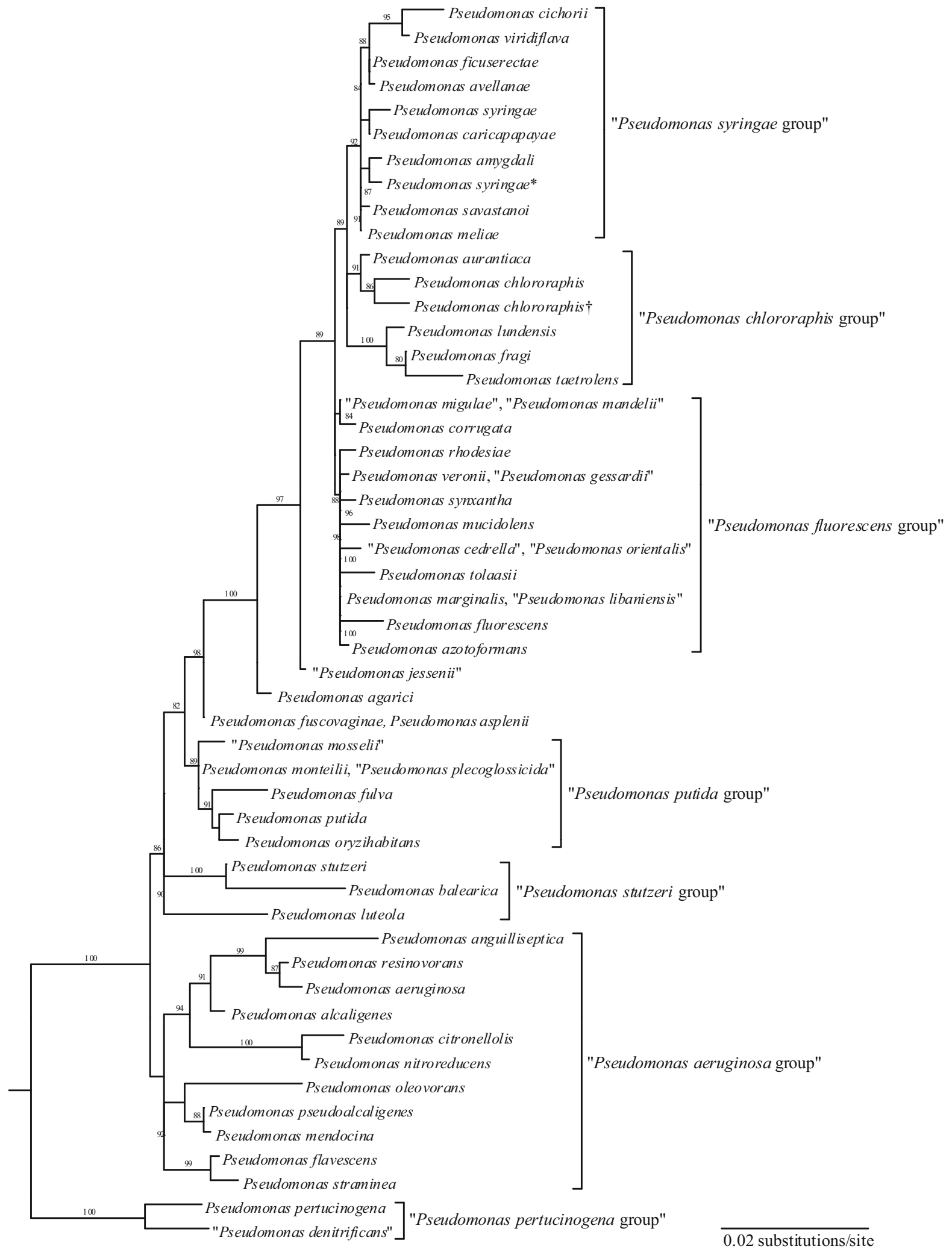


Table 1 Biopesticide products and genetically modified (GM) crops utilizing Pseudomonas spp. (Only naturally occurring strains of Pseudomonas spp. are reported) or a related species as the donor source

\begin{tabular}{|c|c|c|c|}
\hline Species (strain) & $\begin{array}{l}\text { Date first } \\
\text { approved }^{\mathrm{a}}\end{array}$ & Product names & Use in agriculture \\
\hline $\begin{array}{l}\text { Pseudomonas syringae strains } \\
\text { ESC-10 and ESC-11 }\end{array}$ & $\begin{array}{l}1990 \text { and } \\
1996 \\
\text { (US- } \\
\text { EPA) }\end{array}$ & $\begin{array}{l}\text { Bio-Save }{ }^{\circledR} 10 \text { LP and Bio- } \\
\text { Save }^{\circledR} 11 \text { LP }\end{array}$ & $\begin{array}{l}\text { Biopesticide - post-harvest fungicide to prevent } \\
\text { contamination of stored fruits and potato (US-EPA } \\
\text { 1999b, 2001a, 2009b) }\end{array}$ \\
\hline $\begin{array}{l}\text { Pseudomonas fluorescens strain } \\
\text { A506 }\end{array}$ & $\begin{array}{l}1992 \text { (US- } \\
\text { EPA) }\end{array}$ & FrostBan $^{\mathrm{TM}}$ & $\begin{array}{l}\text { Biopesticide-provides protection from frost and } \\
\text { suppresses bacterial pathogens (US-EPA 1992b) }\end{array}$ \\
\hline $\begin{array}{l}\text { Pseudomonas aureofaciens } \\
\text { strain } \mathrm{Tx}-1\end{array}$ & $\begin{array}{l}1999 \text { (US- } \\
\text { EPA) }\end{array}$ & Bio-Ject $^{\circledR}$ Spot-Less ${ }^{\mathrm{TM}}$ & $\begin{array}{l}\text { Biopesticide-foliar treatment for fungal pathogens } \\
\text { on golf course turf (US-EPA 1999a, 2000) }\end{array}$ \\
\hline $\begin{array}{l}\text { Pseudomonas chlororaphis } \\
\text { strain } 63-28\end{array}$ & $\begin{array}{l}\text { 2001(US- } \\
\text { EPA) }\end{array}$ & AtEze $^{\mathrm{TM}}$ & $\begin{array}{l}\text { Biopesticide-protection against fungal pathogens in } \\
\text { greenhouse ornamentals and vegetables (US-EPA } \\
\text { 2001b, 2001d) }\end{array}$ \\
\hline $\begin{array}{l}\text { Pseudomonas sp. strain DSMZ } \\
\text { 13134; closely related to } \\
\text { P. fluorescens) }\end{array}$ & $\begin{array}{l}2012 \\
(\text { EFSA })\end{array}$ & Proradix ${ }^{\circledR}$ & $\begin{array}{l}\text { Biopesticide-protection against fungal diseases in } \\
\text { vegetables and flowers (Buddrus-Schiemann et al. } \\
\text { 2010; EFSA 2012) }\end{array}$ \\
\hline $\begin{array}{l}\text { Pseudomonas fluorescens strain } \\
\text { D7 }\end{array}$ & $\begin{array}{l}2014 \\
(\text { EPA) }\end{array}$ & $\mathrm{D} 7^{\circledR}$ & $\begin{array}{l}\text { Biopesticide-suppression of certain invasive grass } \\
\text { species (US-EPA 2014) }\end{array}$ \\
\hline $\begin{array}{l}\text { Pseudomonas chlororaphis } \\
\text { strain MA } 342\end{array}$ & $\begin{array}{l}2016 \\
(\text { EFSA })\end{array}$ & Cedomon $^{\circledR}$ and Cerall ${ }^{\circledR}$ & $\begin{array}{l}\text { Biopesticide-protection against fungal pathogens } \\
\text { on cereals (EFSA 2017) }\end{array}$ \\
\hline $\begin{array}{l}\text { Pseudomonas chlororaphis } \\
\text { strain AFS009 }\end{array}$ & $\begin{array}{l}2017 \\
(\text { EPA) }\end{array}$ & $\begin{array}{l}\text { Howler }^{\mathrm{TM}}, \text { Howler }^{\mathrm{TM}} \\
\text { Technical, and Howler } \\
\text { T\&O }\end{array}$ & $\begin{array}{l}\text { Biopesticide-fungicide for turf and ornamental } \\
\text { plants (AgBiome 2017; US-EPA 2017a) }\end{array}$ \\
\hline $\begin{array}{l}\text { Pseudomonas chlororaphis } \\
\text { strain G65 }\end{array}$ & $\begin{array}{l}1995 \\
\text { (USDA) }\end{array}$ & $\begin{array}{l}\text { Event } 8338 \text { tomatoes; } \\
\text { OECD Unique Identifier } \\
\text { CGN-89322-3 }\end{array}$ & $\begin{array}{l}\text { Gene donor for GM crop-Accd gene encodes the } \\
\text { 1-amino-cyclopropane-1-carboxylic acid } \\
\text { deaminase (ACCd) enzyme which reduces ethylene } \\
\text { production and delays ripening (USDA-APHIS } \\
\text { 1995). }\end{array}$ \\
\hline $\begin{array}{l}\text { Pseudomonas fluorescens strain } \\
\text { A32 }\end{array}$ & $\begin{array}{l}2013 \\
(\mathrm{USDA})\end{array}$ & $\begin{array}{l}\text { Soybean event FG72; } \\
\text { OECD Unique Identifier } \\
\text { MST-FG } \varnothing 72-2\end{array}$ & $\begin{array}{l}\text { Gene donor for GM crop-Source of recombinant } \\
\text { DNA for GM crop; confers tolerance to } \\
\text { isoxaflutole (IFT) herbicides when expressed in } \\
\text { plants (USDA-APHIS 2013) }\end{array}$ \\
\hline \multirow[t]{3}{*}{$\begin{array}{l}\text { Delftia acidovorans (formerly } \\
\text { classified as Pseudomonas } \\
\text { acidovorans) }\end{array}$} & $\begin{array}{l}2014 \\
(\text { USDA) }\end{array}$ & $\begin{array}{l}\text { OECD Unique Identifier } \\
\text { DAS-68416-4 }\end{array}$ & $\begin{array}{l}\text { Gene donor for GM crop-Source of recombinant } \\
\text { DNA for GM crop-confers tolerance to } \\
\text { aryloxyalkanoate herbicides when expressed in } \\
\text { plants (USDA-APHIS 2014b) }\end{array}$ \\
\hline & $\begin{array}{l}2014 \\
\text { (USDA) }\end{array}$ & $\begin{array}{l}\text { OECD Unique Identifier } \\
\text { DAS-44406-6 }\end{array}$ & $\begin{array}{l}\text { Gene donor for GM crop-Source of recombinant } \\
\text { DNA for GM crop-confers tolerance to } \\
\text { aryloxyalkanoate herbicides when expressed in } \\
\text { plants (USDA-APHIS 2014a) }\end{array}$ \\
\hline & $\begin{array}{l}2015 \\
(\text { USDA) }\end{array}$ & $\begin{array}{l}\text { OECD Unique Identifiers } \\
\text { DAS-81910-7 }\end{array}$ & $\begin{array}{l}\text { Gene donor for GM crop-Source of recombinant } \\
\text { DNA for GM crop-confers tolerance to } \\
\text { aryloxyalkanoate herbicides when expressed in } \\
\text { plants (USDA-APHIS 2015) }\end{array}$ \\
\hline
\end{tabular}

${ }^{\mathrm{a} U S-E P A}$ date indicates date first registered by the US Environmental Protection Agency (US-EPA 2017b); EFSA date indicates date first approved by the European Food Safety Authority (EFSA 2012, 2017); USDA date indicates date deregulated by US Department of Agriculture (USDA-APHIS 2017) 
(Kupferschmied et al. 2013). Similarly, other species of Pseudomonas, including P. chlororaphis, $P$. protegens and $P$. aeruginosa, have demonstrated insecticidal activity (see Table 2 of Kupferschmied et al. 2013). Because of their role in plant protection and defense, P. chlororaphis and other Pseudomonas species with biopesticidal activity are being marketed for use as seed-treatment and foliar-applied biopesticides or as gene donors for GM crops (Kupferschmied et al. 2013).

History of safe use in agriculture

\section{Pseudomonas-based biopesticides and plant protection products}

Several biopesticide products containing Pseudomonas species that provide protection against fungal pathogens and diseases have been developed and assessed for their safety (Table 1). For example, two strains of $P$. syringae (ESC-10 and ESC-11) have been shown to control post-harvest mold contamination on certain fruits, and dry rot and silver scurf on potatoes during storage (US-EPA 1999b, 2001a, 2009b). The products developed with these strains emphasize the long history of safe use of Pseudomonas-based biopesticides, as they were first registered with the United States Environmental Protection Agency (US-EPA) in 1990 and 1996 (USEPA 2017b). Over the past 30 years, several additional Pseudomonas-based biopesticides and plant protection products have been registered with the USEPA or approved by the European Food Safety Authority (EFSA); this further demonstrates the long history of safety (Table 1). For example, Pseudomonas sp. DSMZ 13134, which is closely related to $P$. fluorescens, has been shown to provide protection against fungal diseases in vegetables and flowers (Buddrus-Schiemann et al. 2010; EFSA 2012), and $P$. aureofaciens strain Tx-1 has been shown to provide protection against fungal pathogens on golf course turf (US-EPA 1999a, 2000). P. chlororaphis strain AFS009 is being leveraged to provide protection against a range of soil-borne fungal pathogens (AgBiome 2017; US-EPA 2017a), and other strains of $P$. chlororaphis (strains MA 342 and 63-28) have been shown to control fungal pathogens in cereals (EFSA 2017; Johnsson et al. 1998), as well as in greenhouse ornamentals and vegetable crops (US-
EPA 2001b, d). In addition to fungal protection, Pseudomonas-based products are used to protect plants against frost damage. For example, $P$. syringae is known to protect plant leaves from frost through ice nucleation (Hirano and Upper 2000), and a non-frostforming strain of $P$. fluorescens (strain A506) is being used to reduce frost damage on fruit and vegetable crops (Nufarm Americas Inc. 2012; US-EPA 1992b). The same strain of $P$. fluorescens is also being used to suppress pathogenic bacterial growth (e.g., fire blight and russet inducing bacteria) on apple and pear crops (Nufarm Americas Inc. 2012; US-EPA 1992b), whereas P. fluorescens strain D7 is being used to suppress growth of certain invasive grass species (USEPA 2014).

As part of the registration requirements of biopesticide products, environmental and human health risk assessments are conducted prior to commercialization (US-EPA 2017c). The US-EPA concluded that these Pseudomonas strains are low risk, therefore these strains were granted exemptions from the requirement for a tolerance (40 CFR Parts 180.1114, 180.1145, $180.1212,180.1304,180.1326$ and 180.1341). The human health and environmental safety of $P$. chlororaphis strain 63-28 and $P$. aureofaciens strain Tx-1 have been reviewed by the US-EPA. Both strains were determined to have no toxicity or human health concerns (US-EPA 2000, 2001d). Similarly, the human health and environmental safety of $P$. chlororaphis strains MA 342 and DSMZ 13134 have been reviewed by the European Commission (EC 2002; Velivelli et al. 2014) and EFSA (2012, 2017). For strain MA 342, the European Commission acknowledged that there were no signs of toxicity or pathogenicity based on a rat acute oral study, and $P$. chlororaphis is unlikely to grow at mammalian body temperature (EC 2002); EFSA recommended additional studies to finalize the risk assessment (EFSA 2017). For DSMZ 13134, EFSA concluded that this strain of $P$. chlororaphis is unlikely to cause toxicity or pathogenicity via oral exposure based on clinical and other experimental data (EFSA 2012).

Pseudomonas syringae strains ESC-10 and ESC-11 and $P$. fluorescens strain A506 were registered with the US-EPA in the early 1990s. According to the USEPA, these strains of $P$. syringae pose low risk to humans or birds because they do not survive at temperatures above $32{ }^{\circ} \mathrm{C}$, and they do not cause adverse effects in mammals when ingested, inhaled or 
applied topically (US-EPA 2009b). Similarly, P. fluorescens is ubiquitous in the environment, is not generally considered to be a human or animal pathogen (US-EPA 1992a) and is not expected to have adverse ecological effects on avian wildlife, aquatic organisms, non-target insects, mammalian systems or endangered species (US-EPA 1992a, 2009a).

\section{Pseudomonas species and related species as a gene source for GM Crops}

Certain Pseudomonas species and related species have also served as gene sources for genetically modified crops (Table 1). The GM crop products developed with these strains also emphasize the long history of safe use of Pseudomonas species as gene donors, as the first GM crop containing a gene from P. chlororaphis was deregulated by the United States Department of Agriculture (USDA) in 1995 (USDA-APHIS 1995, 2017). Event 8338 tomato (OECD Unique Identifier CGN-89322-3) was developed by Monsanto (Monsanto Company 1995). These GM tomatoes contain a gene from $P$. chlororaphis that encodes the 1-amino-cyclopropane-1-carboxylic acid deaminase (ACCd) enzyme, which has been shown to delay ripening when expressed in tomato plants by reducing ethylene production.

Similarly, in 2013 and 2014, the USDA deregulated four herbicide tolerant GM soybean and cotton varieties that were developed with genes from $P$. $f u$ orescens and Delftia acidovorans (USDA-APHIS 2017). The gene from $P$. fluorescens encodes the hydroxyphenylpyruvate dioxygenase (HPPD) protein, which has been demonstrated to confer tolerance to isoxaflutole (IFT) herbicides when expressed in plants. Bayer CropScience developed herbicide tolerant soybean event FG72 (OECD Unique Identifier MSTFGØ72-2) using the HPPD W366 gene from P. fluorescens strain A32 (USDA-APHIS 2013). The gene from $D$. acidovorans has been demonstrated to confer tolerance to aryloxyalkanoate herbicides by expression of the aryloxyalkanoate dioxygenase-12 (AAD-12) protein. Herbicide tolerance traits have been developed using the aad-12 gene from $D$. acidovorans in soybean and cotton by Dow AgroSciences LLC [OECD Unique Identifiers DAS-44406-6; DAS-68416-4 and DAS81910-7 (USDA-APHIS 2014a, b, 2015), respectively]. Delftia acidovorans was previously classified as Pseudomonas acidovorans and Comamonas acidovorans, before being reclassified recently as Delftia (Dow AgroSciences 2010; Tamaoka et al. 1987). The safety of both $P$. fluorescens and $D$. acidovorans as a gene sources for GM crops has been assessed by several regulatory authorities [for example, EFSA (2015a), FSANZ (2013), USDA-APHIS (2013) and CFIA (2013), FSANZ (2014), Health Canada (2014), USDA-APHIS (2014c), respectively]. Based on this and other evidence, GM soybean containing the gene from $P$. fluorescens and the GM soybean and cotton events containing the gene from $D$. acidovorans have been approved by several regulatory authorities globally (ISAAA 2018).

Pathogenic, toxic or allergenic properties

As previously reviewed by Leuschner et al. (2010), regulatory authorities in the US and Europe concluded that $P$. chlororaphis strains used for plant protection purposes pose no health concerns for humans (EC 2002; US-EPA 2001d). Additionally, P. chlororaphis was previously reviewed by EFSA using a Qualified Presumption of Safety (QPS) Approach (EFSA 2015b), which included a thorough assessment of the species' life history characteristics, commercial uses and safety concerns. The thorough review of $P$. chlororaphis safety resulted in a general consensus that it is non-pathogenic to humans and livestock because of its inability to grow and proliferate at mammalian body temperatures (EC 2002). Based on this weight of evidence, $P$. chlororaphis was determined to be safe for biocontrol applications (Chen et al. 2015).

While there have been a few reports where $P$. chlororaphis has been isolated from animals with disease or illness (for example, Hatai et al. 1975), these reports are rare and there has been no causal link to clinical illness (EC 2002; EFSA 2015b). As part of the QPS evaluation, microorganisms are considered within the context that they are "deliberately introduced in the food chain either directly or as a source of additive or food enzyme" (Leuschner et al. 2010). The QPS assessment does not consider the organism's safety for use as a gene source for GM crops, therefore the utility of this QPS assessment is limited to applications where the organism is either used directly or as a source of additive or food enzyme in food and feed applications. The QPS assessment for P. chlororaphis noted that it may produce secondary 
metabolites (for example, rhamnolipids and phenazine compounds) (EFSA 2015b). However, the potential for a gene source to produce a secondary metabolite like rhamolipids or phenazine compounds does not indicate inherent risk for the GM crop. Secondary metabolites like rhamolipids or phenazine compounds are synthesized through complex biochemical pathways involving multiple genes. For example, rhamnolipids biosynthesis occurs in sequential reactions catalyzed by RhlA, RhlB and RhlC proteins [under the control of the rhlA, rhlB and $r h l C$ genes, respectively (Gunther et al. 2005; Reis et al. 2011)]. Biosynthesis of phenazine compounds is controlled by $p h z$ genes (Dowling and O'Gara 1994). The safety of the specific gene inserted into the plant and gene products is assessed as part of the safety assessment of GM crops, and there is no evidence to suggest that the ipd072Aa gene from $P$. chlororaphis is involved in the biosynthesis of secondary metabolites like rhamnolipids or phenazine compounds.

\section{Phylogenetic relatedness to known human and plant pathogens}

There is currently a robust understanding of the phylogenetic relatedness within the genus Pseudomonas (Anzai et al. 2000; Burr et al. 2010; Garrity et al. 2005; Gomila et al. 2015; Moore et al. 2006). The Pseudomonas genus does contain some well-recognized plant and human pathogens, including $P$. aeruginosa and $P$. syringae (Peix et al. 2009). Therefore, the phylogenetic relatedness of pathogenic Pseudomonas species and other Pseudomonas species intended for agricultural applications should be considered before potential use. $P$. aeruginosa is a gram-negative, aerobic bacterium that is relatively ubiquitous in the environment and can be found in soil and water, as well as on the surface of plants. P. aeruginosa is well recognized as both a plant pathogen and an opportunistic human pathogen that can cause respiratory infection in immunocompromised patients (Sadikot et al. 2005). The pathogenicity of $P$. aeruginosa is thought to be related to virulence factors carried by pathogenicity islands. For example, the pathogenicity islands PAPI-1 and PAPI-2 have been linked to the virulence of $P$. aeruginosa. It has been confirmed that $P$. chlororaphis does not contain virulence factors and shares no genomic homology with these known pathogenicity islands (Chen et al. 2015). P. aeruginosa is phylogenetically distant from $P$. chlororaphis (Anzai et al. 2000; EC 2002; Fig. 1).

The pathogenicity of $P$. syringae to plants is well understood. The taxonomy of the species is separated into pathovars, each distinguishable based on the primary host plant(s) and carbon source(s) they utilize for growth (Garrity et al. 2005). The plant pathogenicity of $P$. syringae is based on an array of phytotoxins that produce disease symptoms. For example, $P$. syringae pathovar syringae disrupts the plasma membrane in host plants via production of syringomycins, syringopeptins and syringotoxins. $P$. syringae is phylogenetically distant from $P$. chlororaphis (Anzai et al. 2000; Fig. 1). Additionally, it has been confirmed that $P$. chlororaphis does not contain the genes that code for the biosynthesis of these or other phytotoxins or exoenzymes (cellulases, pectinases, pectin lyases) that compromise plant cell walls (EFSA 2015b).

While it is important to consider phylogenetic relatedness to known pathogens, identifying a pathogen in the same genus as a potential source donor for a GM crop does not indicate inherent risk. Many species share phylogenetic relatedness with known pathogens without being pathogenic themselves. For example, the phylogenetic relatedness of species belonging to the Bacillus genus has been published previously based on 16S rRNA gene sequences (see Fig. 2 in Alcaraz et al. 2010). While Bt shares distant phylogenetic relatedness with a few pathogens (e.g., Bacillus anthracis; Alcaraz et al. 2010), it has a long history of safe use as a biopesticide and as a gene source for GM crops (US-EPA 1998, 2001c). Similarly, the phylogenetic relatedness of species belonging to the Streptomyces genus has been published previously based on 16S rRNA gene sequences (see Fig. 1 in Kämpfer 2006). Very few species of Streptomyces are human, animal or plant pathogens (Kämpfer 2006). For example, Streptomyces scabiei is a well-known plant pathogen associated with potato scab (Zhang et al. 2016), and Streptomyces somaliensis is a human pathogen that causes deep tissue and bone infections (Kirby et al. 2012). Even though phylogenetically related to these pathogens, the safety of Streptomyces viridochromogenes as a gene source for GM crops is well established (OECD 2007). 


\section{Conclusions}

The safety assessment framework for GM crops is well established and is appropriate for assessing traits derived from non- $B t$ source organisms. One component of the safety assessment includes an evaluation of each introduced trait, including its source organism, for potential adverse pathogenic, toxic and allergenic effects. Establishing a history of safe use, and a lack of known allergenic, toxic or pathogenic properties, contributes to the weight of evidence that a gene, and its expression product (protein), derived from a source donor is safe for its intended use, when expressed in a modified crop. Pseudomonas species represent a potential source of genes with insecticidal properties. The ipd072Aa gene from $P$. chlororaphis encodes the IPD072Aa protein, which confers protection against certain coleopteran pests when expressed in maize plants. This paper provides an assessment of the safety of $P$. chlororaphis as a gene source for GM crops. Like Bt, Pseudomonas species are ubiquitous in the environment and several have been utilized in a variety of agricultural and industrial applications. Certain Pseudomonas species, including P. chlororaphis, have been used in biopesticide products and as a gene source for GM crops, and their safety as applied plant protection products has been previously assessed. Although $P$. chlororaphis is distantly related to plant and human pathogens (e.g., P. aeruginosa and $P$. syringae), it is not a human, animal or plant pathogen and has no known potential to cause toxic or allergenic effects in mammals. This information supports, in part, the safety assessment of potential traits, such as IPD072Aa, derived from P. chlororaphis.

Acknowledgements The authors wish to acknowledge and thank Ian Lamb, Bryan Delaney, Greg Dana, Mieko Kasai, Chad Boeckman, Mark Nelson, Daria Schmidt, Mary Locke and many others for their editorial contributions and constructive feedback. The authors also thank Yojiro Anzai for permission to reproduce the Pseudomonas phylogenetic tree in this paper.

\section{Compliance with ethical standards}

Conflict of interest The authors are employees of DuPont Pioneer.

Open Access This article is distributed under the terms of the Creative Commons Attribution 4.0 International License (http:// creativecommons.org/licenses/by/4.0/), which permits unrestricted use, distribution, and reproduction in any medium, provided you give appropriate credit to the original author(s) and the source, provide a link to the Creative Commons license, and indicate if changes were made.

\section{References}

AgBiome (2017) Howler fungicide receives EPA registration. PR Newswire. https://www.prnewswire.com/newsreleases/howler-fungicide-receives-epa-registration300507179.html Accessed 15 Dec 2017

Alcaraz LD, Moreno-Hagelsieb G, Eguiarte LE, Souza V, Herrera-Estrella L, Olmedo G (2010) Understanding the evolutionary relationships and major traits of Bacillus through comparative genomics. BMC Genom 11:332. https://doi.org/10.1186/1471-2164-11-332

Anderson AJ, Kim YC (2018) Biopesticides produced by plantprobiotic Pseudomonas chlororaphis isolates. Crop Prot 105:62-69. https://doi.org/10.1016/j.cropro.2017.11.009

Anderson JA, Gipmans M, Hurst S, Layton R, Nehra N, Pickett J, Shah DM, Souza TLPO, Tripathi L (2016) Emerging agricultural biotechnologies for sustainable agriculture and food security. J Agric Food Chem 64:383-393. https://doi. org/10.1021/acs.jafc.5b04543

Anzai Y, Kim H, Park J-Y, Wakabayashi H, Oyaizu H (2000) Phylogenetic affiliation of the pseudomonads based on $16 \mathrm{~S}$ rRNA sequence. Int J Syst Evol Microbiol 50:1563-1589. https://doi.org/10.1099/00207713-50-4-1563

Buddrus-Schiemann K, Schmid M, Schreiner K, Welzl G, Hartmann A (2010) Root colonization by Pseudomonas sp. DSMZ 13134 and impact on the indigenous rhizosphere bacterial community of barley. Microb Ecol 60:381-393. https://doi.org/10.1007/s00248-010-9720-8

Burr SE, Gobeli S, Kuhnert P, Goldschmidt-Clermont E, Frey J (2010) Pseudomonas chlororaphis subsp. piscium subsp. nov., isolated from freshwater fish. Int J Syst Evol Microbiol 60:2753-2757. https://doi.org/10.1099/ijs.0.011692-0

CFIA (2013) Decision document DD2013-97: Determination of the safety of Dow AgroSciences Canada Inc.'s soybean (Glycine $\max$ (L.) Merr.) event DAS-44406-6. Canadian Food Inspection Agency. http://cera-gmc.org/files/cera/ GmCropDatabase/decdocs/DAS444066/DAS444066 soybean_Canada_envt_feed.pdf

Chen Y, Shen X, Peng H, Hu H, Wang W, Zhang X (2015) Comparative genomic analysis and phenazine production of Pseudomonas chlororaphis, a plant growth-promoting rhizobacterium. Genom Data 4:33-42. https://doi.org/10. 1016/j.gdata.2015.01.006

Codex Alimentarius Commission (2009) Foods derived from modern biotechnology, 2nd edn. Food and Agriculture Organization of the United Nations, World Health Organization, Rome

Delaney B, Astwood JD, Cunny H, Conn RE, Herouet-Guicheney C, MacIntosh S, Meyer LS, Privalle L, Gao Y, Mattsson J (2008) Evaluation of protein safety in the context of agricultural biotechnology. Food Chem Toxicol 46:S71-S97. https://doi.org/10.1016/j.fct.2008.01.045

Dow AgroSciences (2010) Petition for determination of nonregulated status for herbicide tolerant DAS-68416-4 
soybean. Dow AgroSciences LLC. https://www.aphis. usda.gov/brs/aphisdocs/09_34901p.pdf

Dowling DN, O'Gara F (1994) Metabolites of Pseudomonas involved in the biocontrol of plant disease. Trends Biotechnol 12:133-141. https://doi.org/10.1016/01677799(94)90091-4

EC (2002) Opinion of the Scientific Committee on plants on specific questions from the commission regarding the evaluation of Pseudomonas chlororaphis in the context of Council Directive 91/414/EEC. European Commission, Brussels

EFSA (2006) Guidance document of the scientific panel on generically modified organisms for the risk assessment of genetically modified plants and derived food and feed. EFSA J 99:1-100

EFSA (2012) Conclusion on the peer review of the pesticide risk assessment of the active substance Pseudomonas sp. strain DSMZ 13134. EFSA J 10:2954. https://doi.org/10.2903/j. efsa.2012.2954

EFSA (2015a) Scientific Opinion on an application (EFSAGMO-BE-2011-98) for the placing on the market of herbicide-tolerant genetically modified soybean FG72 for food and feed uses, import and processing under Regulation (EC) No 1829/2003 from Bayer CropScience. EFSA J 13:4167. https://doi.org/10.2903/j.efsa.2015.4167

EFSA (2015b) Statement on the update of the list of QPS-recommended biological agents intentionally added to food or feed as notified to EFSA 3: suitability of taxonomic units notified to EFSA until September 2015. EFSA J 13:4331

EFSA (2017) Peer review of the pesticide risk assessment of the active substance Pseudomonas chlororaphis strain MA 342. EFSA J 15:4668. https://doi.org/10.2903/j.efsa.2017. 4668

FAO/WHO (1991) Strategies for assessing the safety of foods produced by biotechnology. Report of Joint FAO/WHO Consultation, Geneva

FSANZ (2013) Application A1051 - food derived from herbicide-tolerant soybean line FG72, safety assessment report (approval). Food Standards Australia New Zealand. http:// cera-gmc.org/files/cera/GmCropDatabase/decdocs/FG72/ FG72_soybean_Australia_food_SafetyAssess.pdf

FSANZ (2014) Approval report-application A1094: Food derived from herbicide-tolerant cotton line DAS-81910-7. Food Standards Australia New Zealand. http://cera-gmc. org/files/cera/GmCropDatabase/decdocs/DAS819107/ DAS819107_cotton_Australia_food.pdf

Garrity G, Brenner DJ, Krieg NR, Staley JR (eds) (2005) Bergey's manual $^{\circledR}$ of systematic bacteriology: volume 2 : the proteobacteria, part B: the gammaproteobacteria. Springer, New York. https://doi.org/10.1007/0-387-28022-7

Gomila M, Peña A, Mulet M, Lalucat J, García-Valdés E (2015) Phylogenomics and systematics in Pseudomonas. Front Microbiol 6:214. https://doi.org/10.3389/fmicb.2015.00214

Gunther NW, Nunez A, Fett W, Solaiman DK (2005) Production of rhamnolipids by Pseudomonas chlororaphis, a nonpathogenic bacterium. Appl Environ Microbiol 71:2288-2293. https://doi.org/10.1128/AEM.71.5.22882293.2005

Hatai K, Egusa S, Nakajima M, Chikahata H (1975) Pseudomonas chlororaphis as a fish pathogen. Bull Jpn Soc Sci Fish 41:1203. https://doi.org/10.2331/suisan.41.1203
Health Canada (2014) Soybean producing aryloxyalkanoate dioxygenase-12 (AAD-12) and phosphinothricin acetyltransferase (PAT) -DAS-68416-4. Int Food Risk Anal J 4:1-3. https://doi.org/10.5772/58798

Hirano SS, Upper CD (2000) Bacteria in the leaf ecosystem with emphasis on Pseudomonas syringae - a pathogen, ice nucleus, and epiphyte. Microbiol Mol Biol Rev 64:624-653

ISAAA (2016) Global status of commercialized biotech/GM crops: 2016 ISAAA Brief No. 52. ISAAA, Ithica, NY

ISAAA's GM Approval Database (2018) http://www.isaaa.org/ gmapprovaldatabase/. Accessed 12018

Johnsson L, Hökeberg M, Gerhardson B (1998) Performance of the Pseudomonas chlororaphis biocontrol agent MA 342 against cereal seed-borne diseases in field experiments. Eur J Plant Pathol 104:701-711. https://doi.org/10.1023/A: 1008632102747

Kämpfer P (2006) The family streptomycetaceae, part i: taxonomy. In: Dworkin M, Falkow S, Rosenberg E, Schleifer K-H, Stackebrandt E (eds) The prokaryotes: volume 3: Archaea. Bacteria: firmicutes, actinomycetes. Springer, New York, pp 538-604

Kirby R, Sangal V, Tucker NP, Zakrzewska-Czerwińska J, Wierzbicka K, Herron PR, Chu C-J, Chandra G, Fahal AH, Goodfellow M (2012) Draft genome sequence of the human pathogen Streptomyces somaliensis, a significant cause of actinomycetoma. J Bacteriol 194:3544-3545. https://doi.org/10.1128/JB.00534-12

Kupferschmied P, Maurhofer M, Keel C (2013) Promise for plant pest control: root-associated pseudomonads with insecticidal activities. Front Plant Sci 4:287. https://doi. org/10.3389/fpls.2013.00287

Leuschner RG, Robinson TP, Hugas M, Cocconcelli PS, Richard-Forget F, Klein G, Licht TR, Nguyen-The C, Querol A, Richardson M (2010) Qualified presumption of safety (QPS): a generic risk assessment approach for biological agents notified to the European Food Safety Authority (EFSA). Trends Food Sci Technol 21:425-435

Luiu L, Satta A, Floris I (2013) Emerging entomopathogenic bacteria for insect pest management. Bull Insectology 66:181-186

Mauchline TH, Malone JG (2017) Life in earth-the root microbiome to the rescue? Curr Opin Microbiol 37:23-28. https://doi.org/10.1016/j.mib.2017.03.005

Mendes R, Kruijt M, de Bruijn I, Dekkers E, van der Voort M, Schneider JH, Piceno YM, DeSantis TZ, Andersen GL, Bakker PA (2011) Deciphering the rhizosphere microbiome for disease-suppressive bacteria. Science 332:1097-1100. https://doi.org/10.1126/science.1203980

Mercado-Blanco J, Bakker PA (2007) Interactions between plants and beneficial Pseudomonas spp.: exploiting bacterial traits for crop protection. Antonie Van Leeuwenhoek 92:367-389

Monsanto Company (1995) Petition for determination of nonregulated status: tomatoes with a delayed ripening gene. Monsanto Company. http://www.cera-gmc.org/files/cera/ GmCropDatabase/docs/decdocs/05-242-013.pdf

Montie TC (ed) (1998) Pseudomonas vol 10. Biotechnology Handbooks, vol 10. Springer, New York. https://doi.org/ 10.1007/978-1-4899-0120-0 
Moore ERB, Tindall BJ, Dos Santos VAM, Pieper DH, Ramos J-L, Palleroni NJ (2006) Nonmedical: Pseudomonas. In: Dworking M, Falkow S, Rosenberg E, Schleifer K-H, Stackebrandt E (eds) The prokaryotes, vol 6. Springer, New York, pp 646-703

Nufarm Americas Inc. (2012) BlightBan ${ }^{\circledR}$ A506, Specimen Label. Nufarm Americas Inc. http://cru66.cahe.wsu.edu/ $\sim$ picol/pdf/WA/57861.pdf

OECD (2007) Consensus document on safety information on transgenic plants expressing Bacillus thuringiensisderived insect control proteins. Organisation for Economic Co-operation and Development, Paris

Peix A, Ramírez-Bahena M-H, Velázquez E (2009) Historical evolution and current status of the taxonomy of genus Pseudomonas. Infect Genet Evol 9:1132-1147. https://doi. org/10.1016/j.meegid.2009.08.001

Reis RS, Pereira AG, Neves BC, Freire DM (2011) Gene regulation of rhamnolipid production in Pseudomonas aeruginosa-a review. Bioresour Technol 102:6377-6384. https://doi.org/10.1016/j.biortech.2011.03.074

Rodríguez H, Fraga R (1999) Phosphate solubilizing bacteria and their role in plant growth promotion. Biotechnol Adv 17:319-339. 9750(99)00014-2

https://doi.org/10.1016/s0734-

Sadikot RT, Blackwell TS, Christman JW, Prince AS (2005) Pathogen-host interactions in Pseudomonas aeruginosa pneumonia. Am J Respir Crit Care Med 171:1209-1223. https://doi.org/10.1164/rccm.200408-1044SO

Schellenberger U, Oral J, Rosen BA, Wei JZ, Zhu G, Xie W, McDonald MJ, Cerf DC, Diehn SH, Crane VC, Sandahl GA, Zhao J-Z, Nowatzki TM, Sethi A, Liu L, Pan Z, Wang Y, Lu AL, Wu G, Liu L (2016) A selective insecticidal protein from Pseudomonas for controlling corn rootworms. Science 354:634-637. https://doi.org/10.1126/science. aaf6056

Schnepf E, Nv Crickmore, Van Rie J, Lereclus D, Baum J, Feitelson J, Zeigler D, Dean D (1998) Bacillus thuringiensis and its pesticidal crystal proteins. Microbiol Mol Biol Rev 62:775-806

Tamaoka J, Ha D-M, Komagata K (1987) Reclassification of Pseudomonas acidovorans den Dooren de Jong 1926 and Pseudomonas testosteroni Marcus and Talalay 1956 as Comamonas acidovorans comb. nov. and Comamonas testosteroni comb. nov., with an emended description of the genus Comamonas. Int J Syst Evol Microbiol 37:52-59. https://doi.org/10.1099/00207713-37-1-52

USDA-APHIS (1995) Determination on a petition 95-053-01p of Monsanto Company seeking nonregulated status for delayed-ripening tomato line 8338. United States Department of Agriculture, Animal and Plant Health Inspection Service. http://www.cera-gmc.org/files/cera/ GmCropDatabase/docs/decdocs/01-290-096.pdf

USDA-APHIS (2013) Bayer CropScience petition (09-328-01p) for determination of non-regulated status of event FG72 soybean, plant pest risk assessment. United States Department of Agriculture, Animal and Plant Health Inspection Service. https://www.aphis.usda.gov/brs/ aphisdocs/09_32801p_fpra.pdf

USDA-APHIS (2014a) Determination of nonregulated status for Dow AgroSciences DAS-44406-6 soybean. United States Department of Agriculture, Animal and Plant Health
Inspection Service. https://www.aphis.usda.gov/brs/ aphisdocs/11_23401p_det.pdf

USDA-APHIS (2014b) Determination of nonregulated status for Dow AgroSciences DAS-68416-4 soybean. United States Department of Agriculture, Animal and Plant Health Inspection Service. https://www.aphis.usda.gov/brs/ aphisdocs/09_34901p_det.pdf

USDA-APHIS (2014c) Record of Decision: Dow AgroSciences petitions (09-233-01p, 09-349-01p, and 11-234-01p) for determination of nonregulated status for 2,4-D-resistant corn and soybean varieties. United States Department of Agriculture, Animal and Plant Health Inspection Service. https://www.aphis.usda.gov/brs/aphisdocs/24d_rod.pdf

USDA-APHIS (2015) Determination of nonregulated status for Dow AgroSciences DAS-81910-7 cotton. United States Department of Agriculture, Animal and Plant Health Inspection Service. https://www.aphis.usda.gov/brs/ aphisdocs/13_26201p_det.pdf

USDA-APHIS (2017) Petitions for determination of nonregulated status. United States Department of Agriculture Animal and Plant Health Inspection Service. https://www. aphis.usda.gov/aphis/ourfocus/biotechnology/permitsnotifications-petitions/petitions/petition-status

USDA-NASS (2017) Crop production historical track records. United States Department of Agriculture, National Agricultural Statistics Service. http://usda.mannlib.cornell.edu/ usda/current/htrcp/htrcp-04-13-2017.pdf

US-EPA (1992a) Briefing memorandum, registration of new biological pesticides: Pseudomonas fluorescens strain A506, Pseudomonas fluorescens strain 1629RS, and Pseudomonas syringae strain 742RS. United States Environmental Protection Agency. https://www3.epa.gov/ pesticides/chem_search/cleared_reviews/csr_PC-006418_ 1-Sep-92_008.pdf

US-EPA (1992b) Notice of pesticide registration-64004-2. United States Environmental Protection Agency. https:// www3.epa.gov/pesticides/chem_search/ppls/06400400002-19920916.pdf

US-EPA (1998) Reregistration Eligibility Decision (RED): Bacillus thuringiensis. United States Environmental Protection Agency, EPA738-R-98-004. https://www3.epa. gov/pesticides/chem_search/reg_actions/reregistration/ red_PC-006400_30-Mar-98.pdf

US-EPA (1999a) Notice of pesticide registration 70688-1. United States Environmental Protection Agency. https:// www3.epa.gov/pesticides/chem_search/ppls/07068800001-19990211.pdf

US-EPA (1999b) Notice of pesticide registration-68182-17. United States Environmental Protection Agency. https:// www3.epa.gov/pesticides/chem_search/ppls/06818200017-19991116.pdf

US-EPA (2000) Pseudomonas aureofaciens strain Tx-1 (006473) technical document. United States Environmental Protection Agency. https://www3.epa.gov/pesticides/ chem_search/reg_actions/registration/related_PC006473_1-Apr-00.pdf

US-EPA (2001a) Notice of pesticide registration-68182-18. United States Environmental Protection Agency. https:// www3.epa.gov/pesticides/chem_search/ppls/06818200018-20010620.pdf 
US-EPA (2001b) Notice of pesticide registration-70688-2. United States Environmental Protection Agency. https:// www3.epa.gov/pesticides/chem_search/ppls/07068800002-20010928.pdf

US-EPA (2001c) Overview; biopesticides registration action document: Bt plant-incorporated protectants. United States Environmental Protection Agency. https://www3.epa.gov/ pesticides/chem_search/reg_actions/pip/bt_brad2/1overview.pdf

US-EPA (2001d) Pseudomonas chlororaphis strain 63-28 (006478) fact sheet. United States Environmental Protection Agency. https://www3.epa.gov/pesticides/chem_ search/reg_actions/registration/fs_PC-006478_01-Apr-01. pdf

US-EPA (2009a) Frost-preventing bacteria: Pseudomonas fluorescens A506 (006438); Pseudomonas fluorescens 1629RS (006439); Pseudomonas syringae 742RS (006411) fact sheet. United States Environmental Protection Agency. https://www3.epa.gov/pesticides/chem_ search/reg_actions/registration/fs_G-136_25-Oct-09.pdf

US-EPA (2009b) Pseudomonas syringae strain ESC-10 (006441), Pseudomonas syringae strain ESC-11 (006451) fact sheet. United States Environmental Protection Agency. https://www3.epa.gov/pesticides/chem_search/ reg_actions/registration/fs_G-149_25-Oct-09.pdf

US-EPA (2014) Notice of pesticide registration-71975-4. United States Environmental Protection Agency. https:// www3.epa.gov/pesticides/chem_search/ppls/07197500004-20140827.pdf

US-EPA (2017a) Notice of pesticide registration-91197-3. United States Environmental Protection Agency. https:// www.regulations.gov/document?D=EPA-HQ-OPP-20160251-0019 Accessed 15 December 2017

US-EPA (2017b) Pesticide chemical search. United States Environmental Protection Agency. https://iaspub.epa.gov/ apex/pesticides/f?p=chemicalsearch: 1

US-EPA (2017c) Pesticide registration manual: Chapter 2registering a pesticide product. United States Environmental Protection Agency. https://www.epa.gov/pesticideregistration/pesticide-registration-manual-chapter-2registering-pesticide-product

Velivelli SLS, Paul DV, Kromann P, Declerck S, Prestwich BD (2014) Biological control agents: from field to market, problems, and challenges. Trends Biotechnol 32:493-496. https://doi.org/10.1016/j.tibtech.2014.07.002

Walsh UF, Morrissey JP, O'Gara F (2001) Pseudomonas for biocontrol of phytopathogens: from functional genomics to commercial exploitation. Curr Opin Biotechnol 12:289-295. https://doi.org/10.1016/S0958-1669(00)00212-3

Zhang Y, Bignell DR, Zuo R, Fan Q, Huguet-Tapia JC, Ding Y, Loria R (2016) Promiscuous pathogenicity islands and phylogeny of pathogenic Streptomyces spp. Mol PlantMicrobe Interact 29:640-650. https://doi.org/10.1094/ MPMI-04-16-0068-R 